\title{
Masyarakat Geopark Gunung Sewu Pacitan Dalam Perspektif Ekonomi, Tradisi Dan Budaya
}

\author{
Erista Zulki Fahrudi dan Dheny Wiratmoko \\ Program Studi Pendidikan Sejarah STKIP PGRI PACITAN
}

\begin{abstract}
Abstrak
Geopark gunung sewu dengan suasana pedesaannya menyimpan banyak keindahan didalamnya termasuk salah satunya adalah pantai. Wilayah yang tidak hanya konservasi namun, juga keindahan dan kekayaan alamnya dimanfaatkan untuk kepentingan ekonomi masyarakat. Pacitan adalah salah satu didalamnya. Meskipun belum semua, sebagian destinasinya telah dikelola Pemda. Dengan adanya kepariwisataan pada wilayah gunung sewu Pacitan diharapkan perekonomian masyarakat bisa tumbuh dan mengangkat taraf kehidupan mereka. Dengan dua wilayah yaitu pesisir pantai dan pegunungan membuat masyarakat berkebudayaan berbada. Daerah pantai maju dengan pariwisata pantainya, sedang daerah yang tidak berada di garis pantai memanfaatkan kekayaan alam yang ada didalamnya. Pertanian menjadi lahan dan penghasilan utama bagi sebagian besar penduduk Pacitan. Apabila kesulitan mencari pekerjaan di sekitar, mereka merantau keluar baik ke kota maupun luar kota. Selain itu sebagai masyarakat tradisional menjaga dan melestarikan tradisi leluhur tetap dipegang teguh oleh masyarakat sekitar.
\end{abstract}

\section{Kata Kunci: Masyarakat, Gunung Sewu, Pacitan}

\section{Pendahuluan}

Pacitan menjadi salah satu kabupaten dengan Pegunungan Sewu kars bagian dari geopark dunia. Geopark Gunung Sewu telah diakui UNESCO sebagai wilyah konservasi geopark dunia. Geopark Gunung Sewu tersebut membentang melewati tiga Kabupaten dan tiga Provinsi, Gunung Kidul Yogyakarta, Wonogiri Jawa Tengah dan Pacitan Jawa Timur. Pegunungan Sewu di Pacitan terletak di bagian barat kota sampai perbatasan Wonogiri Jawa Tengah.

Pegunungan Sewu di Pacitan pada umumnya terletak di wilayah pedesaan yang umumnya perekonomian kurang berkembang didalamnya dengan mata pencaharian masyakakatnya kebanyakan agraris. Agraris pada wilayah pegunungan kurang begitu subur, hanya musim hujan saja lahan bisa ditanami sedangkan kalau musim kering lahan kurang produktif, hanya tanaman taunan saja yang bisa menghasilkan seperti kayu, kelapa dan tanaman pakan ternak.

Kemajuan zaman menuntut masyarakat untuk lebih berkembang dan lebih kreatif dalam memenuhi kebutuhan mereka. Kemampuan mengolah sumber daya yang ada menjadi nilai yang sangat menentukan saat semua orang berlombalomba untuk mencapai sebuah kesejahteraan. Tuntutan kebutuhan memaksa mereka untuk bisa menghasilkan uang atau modal tambahan dan tidak hanya mengandalkan penghasilan dari salah satu pihak keluarga. Beberapa tahun ini mungkin 
banyak berita tentang "geopark" atau yang diterjemahkan sebagai taman bumi dalam Bahasa Indonesia. Secara sederhana, geopark ini dapat diartikan sebagai sebuah kawasan yang mengandung kekayaan dan warisan geologis dan dikembangkan secara berkelanjutan untuk kepentingan pemberdayaan masyarakat, pendidikan dan ilmu pengetahuan, kebudayaan dan konservasi.

Tujuan dari pendirian geopark diutamakan untuk pembangunan perekonomian, pendidikan dan konservasi alam. Pemberdayaan masyarakat lokal menjadi prioritas pembangunan perekononian di kawasan geopark menjadi sebuah pariwisata yang berkelanjutan. Pariwisata berkelanjutan adalah salah satu cara untuk pemberdayaan masyarakat lokal. Aktivitas pariwisata selanjutnya harus memperhatikan kesesuaian dengan kondisi dan kearifan lokal serta menghormati karakter budaya masyarakat setempat.

Pengembangan geo-toursim sangat relevan dan realistis untuk kawasan ini. Selain itu perkembangan ekonomi kreatif dalam bentuk industri pariwisata semacam kerajinan, kesenian, jasa pemandu, jasa transportasi/tourism organizer dan akomodasi dapat menjadi efek dominan dari kawasan geopark untuk masyarakat lokal. Selain itu konsep wisata budaya juga dapat dikedepankan untuk menampilkan budaya lokal dalam bersinergi dengan kearifan alam. Namun jangan sampai investasi di tempat ini malah mengalahkan dan menyisihkan masyarakat dan budaya lokal. Peran pemerintah sangat penting untuk melindungi dan mengembangkan masyarakat dengan budaya dan kearifan lokalnya.

Penguatan budaya lokal seperti kesenian tari agar dapat dikemas menjadi pertunjukan bagi wisatawan serta pemberian pengetahuan mengenai pariwisata berkelanjutan dan perlindungan alam agar kawasan dapat terjaga kelestariannya. Selain itu, kawasan goepark juga dapat dijadikan media edukasi mengenai pengetahuan alam, proses terjadinya planet bumi.

Reformasi ekonomi di Indonesia perlu ditegaskan dengan adanya pendekatan pengembangan ekonomi mikro yang lebih berorientasi kepada masyarakat. Hal ini dimaksudkan agar proses pemberdayaan ekonomi menjadi milik masyarakat dalam arti yang sesungguhnya, sehingga format ekonomi kerakyatan lebih mengacu pada konsepsi-konsepsi masyarakat terhadap pemberdayaan ekonomi dimana masyarakat tidak hanya menjadi objek ekonomi makro.

\section{Tinjauan Pustaka}

Kemiskinan yang timbul akibat terbatasnya jumlah sumber daya atau tingkat perkembangan teknologi yang sangat rendah. Artinya faktor-faktor yang menyebabkan suatu masyarakat menjadi 
miskin secara alami memang ada, dan bahkana akan ada kelompok atau individu di dalam masyarakat tersebut yang lebih miskin dari yang lain. Kemiskinan alamiah tersebut akan terdapat perbedaanperbedaan kekayaan, seperti pola hubungan patron-client, jiwa gotong royong dan sejenisnya yang fungsional untuk meredam kemungkinan timbulnya kecemburuan sosial (Puji Hadiyanti 2005: 36).

Melalui pengembangan Geopark nilai ekonomi masyarakat setempat akan ditingkatkan, selaras dengan kegiatan konservasi berkelanjutan dan pendidikan yang menjadi kegiatan di dalam kawasan. Geopark menjadi bentuk apresiasi kita semua kepada nilai dan makna keunikan, kelangkaan dan estetika dari keragaman dan warisan geologi yang terdapat di suatu kawasan. Ditopang oleh pilar pembangunan berkelanjutan, pengembangan wilayah berciri khusus seperti itu ditujukan kepada masyarakat setempat yang tinggal di dalam dan di sekitar kawasan geopark.

Dengan demikian, masyarakat setempat akan merasakan manfaat yang diperoleh secara langsung atau tidak langsung dari kegiatan pembangunan geopark. Oleh karenanya, sesuai dengan tujuan pembangunan geopark, konsep ini mempunyai hakekat merayakan dan membangun kembali hubungan antara alam dengan manusia. Sebelum manusia ada, alam telah membentuk hubungan yang harmoni dengan binatang dan tumbuhan.
Mengingat pentingnya peranan geopark dalam meningkatkan ekonomi masyarakat perlu dikembangkan sebagai objek tempat wisata, untuk itu diharapkan dengan adanya geopark pemberdayaan ekonomi masyarakat mulai tumbuh dan meningkat.

Mengenai Geopark Gunung Sewu atau kars tersebut, masyarakat kurang begitu tahu akan hal itu. Mereka lahir dan tinggal di wilayah tersebut, dengan kondisi alamnya yang begitu, memanfaatkan hasilnya. Hanya baru-baru ini saja setelah adanya pembangunan menuju pantai-pantai kars yang berada di Pacitan, ada sebagian dari mereka berpindah profesi menjadi pedagang di sekitar pantai. Walau begitu penduduk sekitar pantai yang tidak melaut masih memanfaatkan lahan pertaniannya untuk mencari rejeki. Kerutinan yang dilakukan masyarakat membuat mereka bersahaja "narimo ing pandum".

Masyarakat yang tidak tinggal di garis pantai, mereka lebih mengusahakan pertanian ladang sebagai sumber pangan dan kebutuhan. Lingkungan alam pegunungan berhasil diusahakan dan dimanfaatkan meski hasilnya untuk tanaman pangan kurang menguntungkan, penanaman lahan gunung dijadikan perkayuan dengan memetik hasilnya kurang lebih tujuh sampai sepuluh tahun. Tersebut bisa dilihat dalam masyarakat pegunungan di geopark Gunung Sewu Pacitan, lahan gunung yang ditanami kayu berhasil membawa dampak yang cukup menopang 
kebutuhan masyarakatnya. Kurang lebih tahun 1972 dan sesudahnya dilakukan penghijauan pada wilayah pegunungan di Pacitan. Bisa dilihat saat ini, pada masa itu rumah hanya memakai bambu sebagai dindingnya, hanya orang terpandang saja yang menggunakan rumah kayu, namun kini dampak dari penghijauan sudah banyak rumah kayu bahkan tembok yang berdiri di pedesaan yang kayunya berasal dari hasil gunung-gunung yang ditanami pohon tersebut.

Berkembangnya teknologi informasi telah merambah sampai pelosok desa, untuk pembelian HP, sepeda motor, bahkan mobil juga hasil penjualan kayu pegunungan, meskipun umtuk mobil ada sebagian yang dari hasil rantau. Keberadaan geopark Gunung Sewu sebagai objek wisata di Kabupaten Pacitan yang berada di pesisir bagian selatan dengan akses yang kurang, menyebabkan beberapa masalah terutama dalam hal pengelolaan serta pengembangan untuk menjadi komoditas komersial.

Masalah tersebut diantaranya adalah belum adanya sinergi pengembangan antar objek wisata, sehingga masih terdapat ketimpangan pengelolaan pada beberapa objek wisata. Ketimpangan pengelolaan tersebut dapat dilihat dari perkembangan masing-masing objek wisata. Beberapa objek wisata sudah mengalami kemajuan dengan pesat, sedangkan beberapa wisata yang lain masih belum dikembangkan secara optimal. Selain karena keberadaan objek wisata yang menyebar dan akses yang kurang baik, faktor lain penyebab ketimpangan pengelolaan pada kawasan geopark adalah adanya pengelola oleh investor asing. Objek wisata yang dikelola investor asing cenderung lebih berkembang jika dibandingkan dengan yang dikelola oleh orang lokal.

Keterlibatan investor asing sebagai pengelola dan pengembang kawasan wisata geopark Gunung Sewu khususnya di Pacitan berdampak baik bagi ekowisata yang menghasilkan pemasukan bagi daerah. Perkembangan wisata selain berpengaruh positif juga berpengaruh negatife khususnya bagi masyarakat sekitar. Pengaruh negatif tersebut diantaranya adalah kurangnya pemberian kesempatan bagi masyarakat lokal untuk berkontribusi dalam pengembangan objek wisata.

Hal tersebut dapat dilihat dari banyaknya lulusan SMK Pariwisata di Pacitan yang tidak dapat bekerja sesuai dengan bidangnya. Didirikannya penginapan dan restoran oleh para investor juga membawa pengaruh bagi masyarakat lokal, sehingga mereka kalah akan mata pencaharian.

Berdasarkan kondisi yang demikian maka, pengembangan kawasan geopark Gunung Sewu berbasis masyarakat lokal merupakan salah satu ide yang dapat digunakan untuk memperbaiki sistem pengembangan pariwisata di Kabupaten Pacitan. 


\section{Metode Penelitian}

Penelitian ini menggunakan penelitian Kualitatif. Maksudnya peneliti ingin mendeskripsikan suatu kejadian fakta atau data yang sifatnya alami dan natural. Menurut Bogdan dalam Maryono (2010), penelitian kualitatif didasarkan: (1) dasar latar alamiah, dan peneliti sendiri sebagai instrument kunci; (2) dalam penelitian kualitatif akan mendeskripsikan data yang telah ada; (3) dalam penelitian kualitatif akan lebih banyak mementingkan proses daripada hasil;

(4) dalam penelitian kualitatif menggunakan analisis data secara induktif; (5) dalam pendekatan kualitatif lebih mementingkan sifat-sifat dasar dari data yang berhubungan dengan makna. Metode pustaka juga digunakan untuk mencari sumber-sumber yang relevan dalam penelitian. Subjek dari penelitian ini adalah mereka masyarakat yang berada di pesisir Pacitan dan warga geopark Gunung Sewu.

\section{Hasil Dan Pembahasan}

Pacitan merupakan salah satu Kabupaten yang merupakan bagian Jawa Timur. Kabupaten Pacitan terletak di Barat Daya Provinsi Jawa Timur yang berbatasan dengan Provinsi Jawa Tengah. Secara administrasi Pacitan berbatasan dengan Ponorogo (Jawa Timur) dan Wonogiri (Jawa Tengah) di sebelah utara, Trenggalek di sebelah timur, Samudera Indonesia di bagian Selatan. Luas Kabupaten Pacitan
1.389,8716 km (Jawa Timur) dan Wonogiri (Jawa Tengah) di sebelah utara, Trenggalek di sebelah timur, Samudera Indonesia di bagian Selatan.

Luas Kabupaten Pacitan 1.389,8716 km persegi, sebagian berupa bukit dan gunung, jurang terjal dan termasuk deretan pegunungan seribu yang membujur di bagian selatan Pulau Jawa. Kabupaten Pacitan dengan pegunungan seribunya memiliki berbagai potensi pariwisata yang beragam baik wisata alam maupun wisata budaya. Salah satu potensi wisata adalah geopark Gunung Sewu.

Selain masyarakat yang berada di wilayah ekowisata, masyarakat Pacitan masih mengandal pemasukan dari sektor pertaniannya. Bahkan daerah yang tergolong wilayah pantai wisata pun yang tidak sebagai pencari ikan atau nelayan mereka masih bertani di daerah pantai untuk mengisi kebutuhannya. Salah satu warga yang berhasil kami wawancarai yang berdagang di pantai Srau bercerita, hanya sebagian kecil pedagang yang menetap di daerah pariwisata, selain itu bertani menjadi yang utama.

Mereka hanya berdagang saat musim liburan dan akhir pekan dalam artian dagang sebagai sampingan. Pedagang yang menetappun juga untung-untungan kalau ramai dapat banyak, tapi kalau lagi sepi pengunjung tidak dapat untung. Wilayah utara dari pesisir pantai lebih mengandalkan sektor pertaniannya, 
pendapatan diperoleh dengan membuat arang, menjual kayu gelondongan dan sebagian merantau baik di kota maupun di luar kota. Bila kita bepergian melewati jalan-jalan desa akan kita jumpai banyak kayu gelondong yang bertumpuk di pinggir jalan. Kayu dibeli dari masyarakat oleh tengkulak untuk disetorkan ke sekitaran Yogyakarta dan Solo.

Sisa-sisa pohon dan rantingnya yang besar dijadikan arang dan yang kecil jadi kayu bakar. Kayu yang sudah menjadi arang kemudian dibeli pengepul yang selanjutnya disetorkan ke daerah Yogyakarta.

\section{Gunung Sewu Sebagai Objek Wisata}

Geopark Gunung Sewu di Kabupaten Pacitan merupakan kawasan wisata yang pengembangannya harus sejalan dan bersinergi dengan fungsinya. Hal ini dikarenakan geopark merupakan kawasan situs geologi yang keberadaannya harus dilindungi dan dikembangkan dengan konsep yang lebih baik dan berkelanjutan. Sebagaimana tujuan geopark untuk tidak memindah maupun mengubah keberadaan situs asalnya, maka pengembangan kawasan geopark Gunung Sewu hendaknya dilakukan melalui keterlibatan masyarakat lokal.

Salah satu alasan pengembangan kawasan Geopark Gunung Sewu dengan melibatkan masyarakat lokal selain untuk melindungi keberadaan situs geopark juga untuk menghindari adanya ketimpangan dalam pengembangan masing-masing objek wisata yang termasuk ke dalam kawasan
Geopark Gunung Sewu di Kabupaten Pacitan. Beberapa faktor yang menyebabkan adanya ketimpangan dalam pengelolaan kawasan Geopark Gunung Sewu di Kabupaten Pacitan, diantaranya; adalah sistem pengelolaan pada masing-masing objek wisata yang menjadi bagian dari kawasan Geopark Gunung Sewu.

Beberapa objek wisata yang menjadi bagian kawasan Geopark Gunung Sewu telah dikembangkan dan dikelola oleh investor asing, sehingga perkembangannya semakin pesat. Kondisi ini dapat dilihat dari adanya berbagai ketersediaan sarana prasarana pendukung kegiatan pariwisata yang beragam. Seperti kelengkapan sarana transportasi, penginapan, rumah makan, promosi, serta sarana pendukung lain. Pengelolaan objek wisata oleh investor asing, selain berdampak positif juga berdampak negatif bagi kelestarian objek wisata yang ada.

Perkembangan objek wisata yang pesat menjadikan berkurangnnya daya dukung lingkungan objek wisata. Sistem pengelolaan yang tidak memperhatikan prinsip pengembangan geopark menyebabkan perubahan objek wisata dari kondisi aslinya. Pengelolaan objek wisata oleh investor asing menyebabkan terbatasnya kontribusi masyarakat lokal dalam pengembangannya. Persepsi masyarakat di sekitar objek wisata cenderung baik, sedangkan kontribusi masyarakat dalam pengelolaannya masih 
rendah. Hal tersebut menjadi alasan perlunya pengembangan kawasan wisata Geopark Gunung Sewu berbasis masyarakat lokal. Kontribusi masyarakat lokal dalam pengelolaan dan pengembangan kawasan Geopark Gunung Sewu di Kabupaten Pacitan diperlukan sebab masyarakat lokal paling berperan dalam pelestarian objek wisata yang ada. Kontribusi masyarakat lokal dalam pengembangan kawasan Geopark Gunung Sewu sebagai objek wisata berbasis masyarakat lokal, dengan melibatkan masyarakat lokal dalam pengambilan keputusan dan pengelola objek wisata.

Kontribusi oleh masyarakat lokal diantaranya; penyediaan sarana prasarana kegiatan pariwisata seperti penginapan, rumah makan, pemandu wisata, pusat oleholeh dan kerajinan, serta jasa pariwasa lain. Keterlibatan masyarakat lokal dalam kegiatan pariwisata terlaksana dengan adanya kebijakan Kabupaten Pacitan untuk meningkatkan kontribusi masyarakat lokal dalam pengelolaan objek wisata.

Pengembangan kawasan geopark sebagai objek wisata berbasis masyarakat lokal akan tercapai dengan adanya kerjasama baik, antara masyarakat lokal dan pemerintah daerah. Hal ini dikarenakan pemerintah daerah memegang peran penting dalam membuat kebijakan, sedangkan masyarakat lokal berperan dalam pelaksana kegiatan pariwisata. Pengembangan kawasan Geopark Gunung Sewu sebagai objek wisata berbasis masyarakat lokal diharapkan mampu memberdayakan sumberdaya manusia yang ada di Kabupaten Pacitan, sehingga kegiatan pariwisata yang ada dapat menunjang kondisi perekonomian masyarakat khususnya masyarakat lokal di daerah objek wisata.

\section{Masyarakat Pesisir}

Laut dan dengan kekayaan alam didalamnya menyimpan begitu banyak nilai ekonomis, mulai dari terumbu karang sampai airnya yang bisa dimanfaatkan sebagai garam. Pantai di Pacitan tidak semuanya untuk sandaran kapal pencari ikan. Dari sekian pantai di Pacitan hanya beberapa saja yang menjadi labuhan perikanan. Selebihnya hanya dijadikan tempat wisata yang dikelola pemerintah. Pada masyarakat dengan pencaharian sebagai nelayan perekonomian disekitarnya menjadi lebih maju, karena ada percepatan pertumbuhan ekonomi pada sektor penjualan ikan.

Masyarakat dengan hanya pantai sebagai objek wisata mereka cenderung sulit akan keadaan. Bagi yang punya akses ke pantai bisa dagang di sekitar pantai namun, masyarakat dengan kemampuan rendah mereka hidup dari hasil pertaniannya. Hal tersebut bukan tidak mungkin akan membuat masyarakat mencari sumber lain sebagai penghasilan salah satu yang paling populer adalah ke perantauan. Masuknya investor dari luar daerah juga menambah keramaian kawasan 
wisata, baik secara ekonomi maupun pemberdayaan masyarakatnya. Sedikit banyak pekerja dari sektor kepariwisataan merupakan warga setempat untuk wilayah Srau dan Watukarung telah dimasuki investor untuk tambak udang, meskipun belum begitu besar namun diharapkan ada dampak bagi masyarakat setempat.

Klayar adalah salah satu yang terkenal, masyarakat sebagian berdagang baik di pinggir jalan raya maupun yang dekat dengan lokasi wisata. Bagi mereka yang tidak bisa akses pada ekonomi wisata, tetap pada profesi lama, yaitu bertani dan pembuat gula merah. Setiap hari air nira kelapa diambil dua kali sehari, yaitu pagi dan sore.

Nira kelapa dimasak sampai mengental untuk selanjutnya dicetak dalam wadah. Berkembangnya perekonomian daerah pantai dapat dilihat dari rumah dan kendaraan yang dimiliki setiap keluarga. Rata-rata rumah dekat pantai merupakan rumah yang cukup layak, bahkan bisa dikatakan bagus bagi ukuran warga desa.

Kendaraan untuk bepergian baik nongkrong maupun ketika anaknya bersekolah kebanyakan adalah sepeda dengan harga dan CC yang lumayan dengan kisaran dua puluh jutaan yang umumnya masyarakat berkendara dengan sepeda CC 100-125-an. Dengan bertambah pesatnya pariwisata dan pengunjung, disisi lain terjadi masalah lingkungan. Hal klasik adalah sampah yang berserakan di sekitar pantai. Pantai yang seharusnya menjadi wahana berlibur yang menyenangkan malah terganggu. Kurang sadarnya masyarakat pengunjung untuk membuang sampah menjadi pemyebab. Namun tidak bisa disalahkan, pantai masih kurang akan tempat sampah. Jadi, baik pengelola dan pengunjung juga harus punya kesadaran untuk memanajemen sampah dengan baik.

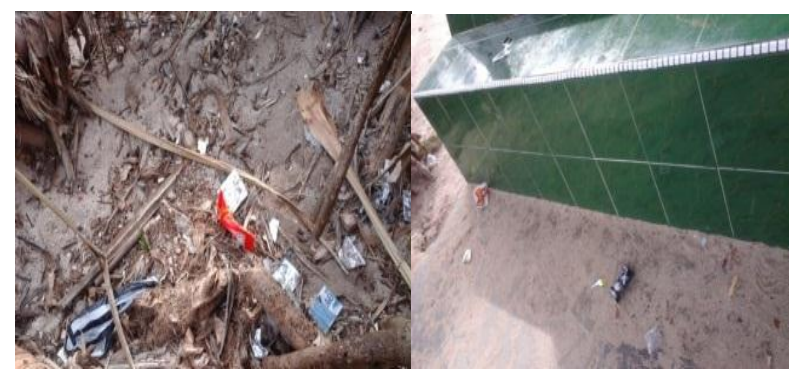

Gambar 1. Potret lingkungan pantai dengan sampahnya

Sumber: Dokumen Pribadi

\section{Masyarakat Tani}

Maksud masyarakat tani disini adalah mereka yang tidak berada di garis pantai pesisir selatan Pacitan. Sebagian besar masyarakat dan lahan di Pacitan adalah pertanian. Khususnya daerah Gunung Sewu, pertanian tidak begitu maju jika dibandingkan dengan Pacitan kota ke timur. Lahan pertanian yang sempit dari setiap penduduk membuat masyarakatnya tidak bisa memenuhi kebutuhan beras setiap tahunnya dari tanaman padinya.

Pada saat panen, yang sekali dalam setahun terkadang hanya cukup untuk makan setahun, malahan banyak diantaranya yang nempur (membeli beras karena kurang). Organisasi dalam bentuk 
kelompok untuk mewadahi masyarakat tani atau yang biasa disebut kelompok tani, menjadi wahana anggotanya untuk bekerjasama dalam hal pertanian misalnya, pembibitan sengon, distribusi pupuk, dan sebagainya. Biasanya untuk mempererat kelompok, diadakan arisan kelompok tani.

Dari sekian lahan yang dimiliki para petani, sebagian yang berupa pegunungan dan lahan yang kurang produktif ditanami pepohonan yang siklus panennya tujuh sampai sepuluh tahun seperti, kayu sengon laut, jabon, gamelina dan lain-lain. Untuk kayu akasia biasanya tumbuh dengan sendirinya melalui benih-benih yang terbawa angin. Kayu jati meskipun banyak tumbuh, ada juga sebagian yang ditanam namun, peminatnya kurang karena siklus panennya lama yang bisa mencapai puluhan tahun bahkan kayu jati yang sudah besar dan tua yang memanen sekarang belum tentu tau kapan dan siapa yang menanam, bisa jadi mbah atau buyutnya.

Selain pertanian, lahan petani desa biasanya juga memelihara ternak sebagai simpanan yang sewaktu-waktu gampang untuk menjualnya. Ternak dipelihara mulai dari kecil hingga beranak-pinak dan digunakan untuk kebutuhan dan kepentingan tertentu. Ternak sebagai suatu harta benda, ada yang dinamakan sistem warisan atau pembagian ternak, misalnya; sapi. Setiap anak diserahi bagian dari hartanya berupa ternak, dimaksudkan untuk membibiti anak agar dimanfaatkan untuk kebutuhannya seperti nikah dan ngopeni keluarganya kelak. Seiring dengan kemajuan zaman, hal tersebut sudah ditinggalkan.

Hal ini karena anak zaman sekarang rata-rata sudah tidak mau lagi mencari rumput dan ngopeni peliharaan. Daripada hidup di desa memelihara ternak yang menunggu beranak, lebih baik mencari kerja ke kota atau luar kota yang setiap bulannya mendapat hasil dan langsung dinikmati. Sengketa lahan, yang terjadi untuk warga pedesaan di Pacitan khususnya wilayah yang masuk kategori geopark adalah persengketaan lahan pegunungan.

Gunung dan lahan pegunungan untuk masa kini menjadi komoditas yang cukup menarik, karena gunung mempunyai nilai ekonomis yang tinggi dan tidak kalah tingginya dengan lahan persawahan. Sengketa lahan gunung tidak lepas dari komoditas kayu yang menyertainya. Warisan masa lalu yang batas dari gunung ditandakan melalui mulut dan batas menurut struktur pegunungan, membuat persengketaan pada anak cucunya.

Batas ditandakan tanah yang ditandakan pada pohon jarak, kayu asem, lereng dan tunggak pohon, lama kelamaan secara alami batas-batas tersebut akan hilang. Termakan usia atau dipindak oknum tertentu, ketika ada suatu yang berharga baik kayu maupun lainnya sering diperebutkan. Meskipun dapat diselesaikan secara musyawarah desa, tapi secara moral, 
hal tersebut bisa dan dimungkinkan terjadi luka panjang dari masing-masing pihak yang mereka simpan dalam hati, meskipun sekilas dilihat masyarakat baik-baik saja.

\section{Sistem Tolong Menolong}

Dalam hidup bermasyarakat setiap orang pasti membutuhkan bantuan orang lain untuk keperluannya. Di desa Jawa biasanya kita kenal dengan nama sambatan yaitu meminta atau membantu keperluan orang lain berupa tenaga. Umumnya di Indonesia dikenal gotong-royong. Untuk kompensasi atas pekerjaannya bukan berupa upah uang, tetapi keluangan tenaga juga yang sewaktu-waktu mempunyai beban moral untuk menggantinya.

Sebagai contoh saat resepsi pengantin, warga desa sambatan untuk membantu segala keperluan hajatan tuan rumah dengan meninggalkan urusan pribadi dan seharian bahkan dua sampai tiga hari. Rasa sebagai sesama warga lingkungan setempat amat kuat, sehingga tanpa upahpun mereka dengan suka rela membantu.

Hal tersebut bergantian dengan tanpa upah dari sang tuan rumah, padahal kalau dihitung secara materi, yang bekerja di tempat tersebut kurang lebih lima puluh orang. Hanya saja mereka berharap nanti bila yang lain punya keperluan, temannya akan bersedia membantu. Sederhana memang, tetapi syarat makna bahwa kebersamaan dibangun untuk meringankan yang lain.

\section{Melestarikan Tradisi}

Tradisi Methek Pari

Pedesaan pada wilayah geopark Pacitan masih cukup kental akan tradisi. Hal tersebut bisa dilihat pada hari dan bulan tertentu yang disucikan untuk melakukan ritual tradisi tersebut. Yang popular adalah ruwat desa atau bersih desa yang masih eksis sampai sekarang.

Lingkungan yang masih alami, seperti sendang, pohon, petilasan, goa membuat tempat tersebut terasa lebih mistis ketika dibumbui dengan ritual tradisi tersebut. Secara lingkungan memang baik, karena bersih desa berarti merapikan dan merawat lingkungan agar tetap terjaga, asri dan lestari. Jika lingkungan menjadi bersih maka, penghuninya merasa nyaman.

Tradisi erat kaitannya dengan simbol, maka dari setiap tempat permintaannya diwujudkan dalam berbagai bentuk dan rupa, ada yang memakau tumpeng, degan makanan tertentu dan sebagainya. Tradisionalitas pedesaan tidak bisa terlepas dengan tradisi masyarakatnya, karena fungsi tradisi erat kaitannya dengan kehidupan yaitu sebagai wadah ekspresi keagamaan, alat pengikat kelompok, benteng pertahanan kelompok, penjaga keseimbangan lahir dan batin (Jamaludin, 2015: 302-303).

Percampuran budaya islam dan lokal juga terjadi dan sampai di Pacitan. Menghasilkan salah satunya budaya methek yang berkembang sampai kini. Methek 
dilakukan pada tanaman padi yang sudah mendekati masa panen. Padi yang di-pethek adalah padi yang menguning paling awal dan hanya satu ikat atau beberapa tangkai saja. Kenduri, Gendhuren, Kondangan, dari ketiga kata tersebut semua maknanya sama yaitu berkumpulnya orang di suatu tempat untuk suatu tujuan.

Umumnya kalau di pedesaan untuk mengadakan atau menghadiri selamatan orang lain, semisal; tingkeban atau tujuh bulanan mengandung, selamatan orang meninggal, sunatan, mantenan dan lain-lain. Adat yang berkembang apabila orang berkumpul seperti itu disuguhi makanan dengan dasar falsafah Jawa "mangan ora mangan kumpul" sampai sekarang falsafah itu masih dipakai, dibuktikan bahwa setiap diadakannya Kenduri pasti disuguhi makanan. Rasa sosial dan solidaritas masyarakat sangat tinggi terutama dalam hal gotong-royong.

Seperti yang dikemukakan Koentjaraningrat (1984), pada umumnya seorang penduduk desa Jawa hanya berhubungan dengan anggota keluarga intinya, dengan para saudara kandung orang tuanya serta anak-anak mereka, dengan kedua kakek dan nenek dari pihak ayah maupun ibunya, dengan anak-anak saudara-saudara kandungnya sendiri dan dengan para iparnya.

Maka, setiap ada kesibukan pada salah satu anggota kerabatnya, kerabat yang lain ikut membantu meringankan bebannya.
Ketika ada Kenduri pada salah satu keluarga, yang lainpun ikut berkunjung merayakan dan meramaikan hajatnya. Tumpeng dan tumpengan sendiri adalah sesuatu yang penting dan harus dalam hajatan orang Jawa, tidak hanya sekedar hiasan atau pelengkap saja, tetapi dari masing-masing tumpeng punya makna dan tujuan tertentu dalam perhelatannya.

Tumpeng adalah gilingan nasi putih atau nasi yang dibuat setengah lingkaran dan tumpeng yang berbentuk lancip seperti kerucut atau dibentuk seperti gunung. Ada bermacam jenis tumpeng yang disajikan pada saat slametan methek, diantaranya:

\section{Tumpeng Besar 3}

Tumpeng merupakan sebuah nasi yang dibentuk seperti gunung yang ujungnya lancip (Pianto, 2016: 167). Tumpeng besar berjumlah tiga buah atau giling yang ditempatkan pada tiga piring berbeda. Dari ketiga tumpeng tersebut masing-masing mempunyai tujuan dan maknanya sendiri-sendiri. Tumpeng pertama ditujukan untuk supaya dalam berumah tangga mendapat ketenteraman dan keselamatan.

Tumpeng kedua permohonan agar diberikan keselamatan dan kebaikan dalam mencari sandang pangan (penghasilan). Tumpeng ketiga, permohonan diberikan kebaikan dan keberkahan dalam melakukan methek. Ketiganya di beri lauk parutan kelapa yang digoreng (serundheng). 
2. Samiran

Tumpeng kecil tumpul dengan jumlah ganjil satu atau tiga buah. Ditempatkan satu piring satu tumpeng samiran dengan lauk parutan kelapa goreng (serundheng). Pembuatan samiran sebagai simbol mengirim atau mendoakan roh leluhur yang sudah meninggal, maka pembuatan dan jumlah samiran disesuaikan dengan anggota keluarga meninggal yang penting berjumlah ganjil.

3. Supitan

Tumpeng tumpul kecil yang diletakkan dua buah dalam setiap piringnya. Jumlahnya berdasarkan hitungan hari baik pada saat melakukan kegiatan methek, misal hari yang digunakan Kamis Wage, maka hitungannya Kamis-8 (wolu), Wage-4 (papat) jumlahnya 12 (rolas), itulah jumlah supitan sebagai patokan. 12 (rolas) tumpeng dengan penetaan setiap piringnya dua berarti enam jodo atau enam piring. Supitan adalah perlambang permohonan doa dan ungkapan rasa syukur karena dari methek sampai panen tidak ada halangan apapun dan semoga hasilnya barokah.

4. Tumpeng Kroyok

Biasa juga disebur tumpeng limo (lima), namun jumlahnya berbeda ada yang memakai lima buah tumpeng dengan salah satu tumpengnya di tengah besar, ada yang memakai tumpeng dengan jumlah tujuh buah. Perlambang dari tumpeng kroyok adalah untuk mendoakan keselamatan dirinya sendiri atau keluarga (tuan rumah).

\section{Jenang Abang}

Jenang atau nasi putih yang diletakkan dalam lambaran kecil sebanyak lima buah (limang nuk) seperti empat penjuru mata angin dengan satu jenang di tengah. Orang jawa biasanya melambangkan "kiblat papat limo pancer" artinya mengarah empat penjuru dan yang kelima adalah titik tengah atau patokannya.

Kelima jenang dihiasi warna yang berbeda, merah, putih, kuning dan hitam.Perlambangan bahwa manusia mempunyai empat arah tujuan atau nafsu dan si pancer jangan sampai salah memilih arah agar tidak terjerumus dalam kesesatan. 6. Jenang Jowo

Jenang menurut arang Jawa adalah bubur, tetapi dalam konteks slametan methek yang digunakan adalah air tawar dari kali atau sumur mentah (towo). Jenang towo biasanya ditempatkan dalam mangkuk atau gelas. Diperlambangkan sebagai penolak bencana dan godaan agar hati tetap putih dan bersih seperti halnya air.

Setelah orang berkumpul untuk melaksanakan hajatan, tuan rumah meminta tetua adat untuk ngujudne (menjelaskan) hajat tuan rumah yaitu slametan methek. Ujud-ujud berarti mewujudkan, menggambarkan dan membaca suatu simbol agar tumpeng tersebut bermakna.

Dalam istilah pewayangan di dalangkan, dalam istilah pernikahan atau mentenan di condro. Berarti dalam kegiatan methek, menjelaskan hajat dan niat tuan 
rumah berdasarkan tumpeng yang dibuat. Pembaca tumpeng disebut tukang ujudujud, menjalaskan mulai hari yang digunakan methek sampai mendoakan arwah leluhur.

\section{Penutup}

\section{Simpulan}

Gunung Sewu yang secara ekonomi pertanian kurang menguntungkan ternyata menyimpan pesona yang luar biasa. Kawasan Gunung Sewu ditetapkan UNESCO sebagai situs geopark yang diakui dunia. Pacitan sebagai salah satu kabupaten dengan wilayah geoparknya dijadikan sebagai destinasi pariwisata untuk menunjang perekonomian masyarakat dan daerah. Namun, hanya wilayah dengan situs dan tempat tertentu saja yang perekonomiannya lebih maju. Terutama kawasan pantai, kegiatan ekonomi dan ekowisata membawa dampak baik bagi perekonomian masyarakat sekitar. Bagi mereka yang kurang dan tidak punya akses ke kawasan wisata tetap dengan pola pertanian mereka.

Tidak semua pantai di Pacitan menjadi sektor nelayan, berarti tidak semua masyarakat pantai hidup dengan perikanan. Mereka hanya sebagian kecil saja yang berdagang di wilayah pantai, selebihnya masih berprofesi sebagai petani dan buruh. Terjadi ketimpangan antar masyarakat pantai. Wilayah yang sudah masuk investor cenderung lebih maju secara perekonomian juga penyerapan tenaga kerja yang lumayan banyak.

Masyarakat dengan tidak memiliki garis pantai masih menghandalkan pertanian dan alamnya sebagai sumber kehidupan dan penghasilan. Begitupun wilayah gunung, tanaman kayu yang tumbuh cukup membantu mengangkat perekonomiannya. Itu dapat dilihat apabila kita berkunjung kepedesaan Gunung Sewu Pacitan, di pinggir-pinggir jalan banyak terdapat tumpukan golondongan kayu yang siap dikirim keluar kota. Selain bertani lahan, petani memelihara ternak sebagai harta yang sewaktu-waktu gampang untuk digunakan.

Identik dengan masyarakat pedesaan yaitu nilai-nilai terutama tradisi yang masih terjaga dan lestari. Salah satu diantaranya yaitu tradisi methek pari yang berada di Desa Sobo Pacitan. Rasa syukur dan doa yang dilambangkan denga tumpeng menambah kesakralan tradisi tersebut. Sistem sambatan dalam masyarakat Jawa menjadikan mereka tetap bersatu guyub rukun.

Sedikit konflik yang terjadi pada wilayah pedesaan dapat diselesaikan secara kekeluargaan demi menghindari masalah yang lebih besar dan proses yang berkepanjangan. Tata nilai yang amat sederhana namun syarat akan makna yang di perkotaan hal tersebut sudah mulai jarang kita jumpai. 


\section{Saran}

Perekonomian masyarakat pedesaan geopark Pacitan kurang merata, hal tersebut bisa kita lihat dari bangunan pada daerah pantai dengan ekonomi perdagangannya dengan masyarakat pedesaan yang latar alamnya ladang dan pegunungan. Peran pemerintah perlu diperdalam dalam hal ekonomi kepariwisataan agar lebih maju dan maksimal.

Masyarakat dengan ladang dan pegunungan, infrastruktur penunjanya sebagai sarana akses ke lahan pertanian dan pegunungan sudah cukup maju jika dibandingkan dengan sepuluh sampai dua puluh tahun yang lalu. Nilai budaya dalam masyarakat seiring dengan berkembangnya jaman mengalami penurunan dengan kurang pedulinya generasi muda pada nilai dan budaya leluhurnya.

\section{Daftar Pustaka}

Daljoeni, N. 1985. Penduduk, Lingkungan Dan Masa Depan. Bandung: Penerbit Alumni.

Daljoeni, N dan Suyitno, A. 1985. Pedesaan, Lingkungan Dan Pembangunan. Bandung: Penerbit Alumni.

Pianto, Heru Arif. 2016. Akulturasi Islam dan Budaya Lokal Pada Tradisi Budaya Tetaken di Pacitan. Makalah disampaikan dalam Seminar Nasional Revitalisasi Kearifan Lokal Untuk Membangun Martabat Bangsa. Surabaya: UNESA. UNIVERSITY PRESS.

Jamaludin, Adon Nasrullah. 2015. Sosiologi Pedesaan. Bandung: Pustaka Setia.

Koentjaraningrat. 1984. Kebudayaan Jawa. Jakarta: PN Balai Pustaka.
Maryono. 2010. Implementasi Kebijakan Sekolah Bertaraf Internasional. JPP. Vol. 2. Nomor 2: 437-444.

Sajogyo dan Sajogyo, Pudjiwati. 2002. Sosiologi Pedesaan: Kumpulan Bacaan. Yogyakartakarta: Gadjah Mada University Press.

Sztompka, Piotr. 1993. Sosiologi Perubahan Sosial. Terjemahan oleh Alimandan. 2004. Jakarta: Prenada 